\title{
Mhjournal
}

\section{Lo siniestro en el texto audiovisual}

José Manuel López-Agulló Pérez-Caballero |josemanuel.lopezagullo@esic.edu ESIC Business \& Marketing School

El presente monográfico encuentra su origen en la asignatura impartida por Jesús González Requena "Conceptualización psicoanalítica" que, debido a la excepcional coyuntura sanitaria, fue impartida online el pasado 2020; razón por la cual, pude disfrutar y participar de ella. El tema de referencia del curso fue "Lo siniestro" y de él, la temática del presente monográfico, "Lo siniestro en el texto audiovisual".

A comienzos del siglo XIX, E.T.A. Hoffmann escribe el que será su relato más célebre, El hombre de la arena, recogido en sus Cuentos nocturnos (1817). Un siglo más tarde, Freud tomará este cuento de Hoffmann como caso de estudio para su elaboración teórica de lo siniestro, que quedará definido como un sentimiento "terrorífico que se remonta a lo familiar desde hace largo tiempo" (1992: 220). Su recién nacida teoría de la neurosis jugará aquí un papel fundamental al hacer de lo siniestro un sentir aterrador producido por el retorno de lo reprimido; sin embargo, Freud deja la puerta abierta en su análisis a la posibilidad de que lo siniestro comparezca más allá de la neurosis.

Acaso sea cierto que lo ominoso (...) sea lo familiar-entrañable (...) que ha experimentado una represión y retorna desde ella, y que todo lo ominoso cumpla esa condición. Pero el enigma de lo ominoso no parece resuelto con la elección de ese material (Freud, 1992: 245).

González Requena se atendrá al hilo de esta argumentación para abordar lo siniestro no desde la perspectiva de la neurosis al modo de Freud, sino de la psicosis. Y es que, de acuerdo con el teórico, lo que experimenta el lector guiado por la voz del narrador en el relato de Hoffmann no es tanto el retorno de lo reprimido, sino la quiebra del Principio de Realidad mismo. Es decir, que el lector de El hombre de la arena se hace testigo de una realidad que no se sostiene, una narración fragmentaria en género epistolar de las experiencias de un protagonista que bordea la locura (González Requena, 1997: 58).

Resulta entonces conveniente situarnos dentro del itinerario elaborado por González Requena acerca de una temática que insiste en su obra no solo a partir de la revisión teórica de los textos de Freud; sino también, por ejemplo, en su afamada clasificación de la historia del cine de Hollywood, que descubrimos en Clásico, Manierista, Postclásico (2008). Lo que nos sitúa en una doble perspectiva para el abordaje de la temática aquí convocada. Una que podría ser clasificada como de revisión histórica dentro del campo del psicoanálisis, ya 
que propone como punto de partida la conceptualización elaborada por su fundador hace ahora más de cien años — "Lo ominoso" data del 1919—. Y otra, más propia del devenir narrativo del aparato cinematográfico.

Esta distinción puede resultar, a priori, peregrina; pero no lo es tanto si tenemos en cuenta que, en el momento en que Freud empieza sus investigaciones sobre lo siniestro, el cine es un discurso técnico aún por construir. ¿Qué quiere decir esto? Que en los inicios del cine, la narratividad no es todavía un hecho consumado, sino un proyecto, todavía en discusión -lo que, de acuerdo con la clasificación de Noël Burch, ha sido popularizado como Modo de Representación Primitivo-, cuyo objeto es hacer de la recién nacida imagen en movimiento un nuevo ámbito discursivo (Burch: 2006).

Según González Requena, existe una fuerte vinculación entre el descubrimiento de la imagen técnica y lo siniestro, en tanto que la primera se presenta al mundo como huella cruda y singular que desafía todo acto intelectivo y proceso narrativo. $\mathrm{Y}$ es que, en sus orígenes, la fotografía escapará a los órdenes semióticos e imaginarios, presentándose así como huella siniestra de lo real.

Podría trazarse la historia de la fotografía, la del cinematógrafo y la de la televisión como, en lo fundamental, una misma historia: la historia de la subversión provocada en el ámbito de la representación por el estallido de lo radical fotográfico. Y la historia de todas las operaciones culturales tendentes a dominarlo, a restaurar de una u otra manera el buen orden de la representación, vale decir, el buen orden del discurso (González Requena, 1998).

A fin de dominar el estallido del así designado "radical fotográfico", en un primer momento, los códigos de la pintura se apoderaron de la fotografía. Y, cuando ya parecía dominada, irrumpió el cinematógrafo que durante unos años no contará con los artificios necesarios para neutralizar nuevamente la voraz expansión de la imagen técnica. Al principio, se siguieron las técnicas formales del teatro y de la pintura, hasta que, poco a poco, se fueron asentando una serie de códigos narrativos capaces de mitigar la huella de la fotografía - lo que en su unicidad brutal tiene de huella de lo real.

Entre 1905 y 1915 el orden semiótico de la representación "consigue someter lo radical fotográfico y dar nacimiento a un nuevo ámbito discursivo que bien podríamos denominar, por oposición, "fílmico"' (González Requena, 1998: 27). Es en este sentido que debemos entender lo "radical fotográfico" —incluso también lo "radical cinematográfico"— como enfrentado al relato del que será capaz el Sistema de Representación Clásico de Hollywood. En palabras de González Requena: "el ultimo gran sistema de representación simbólico que Occidente ha logrado alumbrar" (1998: 28).

Decíamos que lo siniestro atraviesa la obra del teórico y que, implícitamente, articula la clasificación de los Sistemas de Representación de Hollywood en Clásico, Manierista y Postclásico. La hipótesis manejada es que dicha distinción puede ser vislumbrada atendiendo a la posición de la cámara y, en consecuencia, a la gestión de la mirada del espectador (González Requena, 1996: 81).

Repasemos brevemente las diferencias entre estos tres Sistemas de Representación. En el primero de ellos —el filme clásico-, la cámara ocupa la posición de un tercero que en 
ningún momento adopta el punto de vista del personaje. En el filme manierista, la cámara se encuentra atrapada en los pliegues de la trama que se descubre a sí misma como un artificio narrativo. Y, finalmente, en el filme postclásico, la cámara se abisma en la contemplación del horror sin ningún tipo de apoyo simbólico capaz de obturarlo. Es por ello que en lo relativo a la estructura narrativa, explica, el filme clásico es la puesta en práctica del relato simbólico como sistema de representación capaz de amortiguar la devastadora presencia de lo real; el filme manierista significa la deconstrucción de dicho sistema simbólico de representación, y el postclásico, "la aniquilación del relato en el espectáculo escópico" (González Requena, 1996: 82).

Insistamos en la vinculación que el relato simbólico guarda con lo siniestro. Como decíamos, el primero de los sistemas surge con el objetivo de mitigar lo "radical fotográfico"; sin embargo, la propia historia del cine nos irá redescubriendo ese elemento que no logra acomodarse fácilmente al ejercicio de la escritura fílmica. Así, nos encontramos con el ejemplo postclásico de dicha persistencia de lo siniestro en El silencio de los corderos (The Silence of the Lambs, Jonathan Demme, 1991) donde, siguiendo con la argumentación de González Requena, la muerte será fotografiada.

Diríase que el devenir transitivo del relato se detiene para condensarse en el espectáculo —intransitivo - del cadáver. Eso que de lo real en él se manifiesta constituye una amenaza extrema, intolerable, frente a la cual ninguna distancia es posible: se impone con la inmediatez brutal del olor del cuerpo en descomposición (González Requena, 1996: 91).

Desparece así todo ritual simbólico en la representación de la muerte que, en este momento de la historia de la imagen, es capturada por la cámara fotográfica. El cuerpo humano se convierte, de este modo, en objeto de una incesante profanación visual en la que lo "radical fotográfico" reaparece como dato abrupto de lo real. "De manera que la mirada del espectador, como la del personaje, se abisma en la visión de lo siniestro" (González Requena, 1996: 94).

Que la muerte, en el ejemplo de El silencio de los corderos, sea fotografiada no solamente atiende al carácter morboso de la representación postclásica — dispuesta a poner al límite el decoro de la mirada clásica-, sino que apunta a ese retorno de la huella fotográfica que descubríamos con la llegada de la imagen técnica en los albores del surgimiento del cine. "La expansión de lo radical fotográfico se descubre así como la contrapartida, la otra cara, de la dificultad de narrar que padece nuestra contemporaneidad" (González Requena, 1998: 28).

Como vemos, el cine ha intentado deshacerse de su siniestra condición desde sus orígenes a partir de la construcción de un código de articulación simbólica capaz de elaborar un tejido discursivo tan coherente como imaginario; por lo que podríamos entender lo siniestro como un concepto que insiste en la historiografía de la imagen fílmica; sea este mitigado, latente o predominante en el conjunto de la imagen técnica.

Aunque la prioridad otorgada en el presente monográfico haya sido la vía teórica del psicoanálisis aplicada al audiovisual cinematográfico, el lector encontrará una amplia variedad de aproximaciones analíticas dispuestas a participar de un concepto que, como veremos, atraviesa una multitud de producciones textuales desde los ámbitos no solo 
narrativo y cinematográfico, sino también documental, periodístico o, incluso, sonoro.

Se proponen así una serie de artículos que tomarán el audiovisual como campo en que analizar lo siniestro, principalmente desde la perspectiva del género de terror. Nos encontramos aquí con las propuestas de José Ganga Algarra; Javier Sanz Aznar y Juan José Caballero-Molina; y José Manuel López-Agulló Pérez-Caballero. Vinculados con esta primera etiqueta, descubrimos los análisis de Marcos Joaquín Ferrer García y Antonio Francisco Alaminos-Fernández enfocados en los géneros de misterio y ciencia ficción, respectivamente. Mención aparte requieren los artículos de Lorenzo Torres Hortelano y Miguel Muñoz-Garnica que, fuera de las producciones occidentales, escogerán como casos de estudio las obras de los cineastas japoneses Kiyoshi Kurosawa y Akira Kurosawa. El lector podrá descubrir además una aproximación teórica alternativa al estudio de la imagen fílmica; Adrien Faure Carvallo, Diego Calderón Garrido y Josep Gustems Carnicer proponen, de este modo, un análisis de lo siniestro desde la banda de sonido. Y más allá del ámbito de la narrativa cinematográfica, Damián Fernández analizará el caso del asesino en serie Robledo Puch, en el periodismo y cine argentinos, o Fabiola Alcalá Anguiano que, desde la óptica del documental, estudiará los testimonios sobe la guerra contra el narcotráfico en México.

\section{Bibliografía.}

Burch, N. (2006). El tragaluz del infinito. Madrid, España: Cátedra.

Freud, S. (1992). Obras completas. Volumen 17. Buenos Aires, Argentina: Amorrortu.

González Requena, J. (1996). Clásico, manierista, postclásico. Área 5. Revista de Comunicación Audiovisual y Publicitaria, 5, 81-120.

González Requena, J. (2008). Clásico, manierista, postclásico: Los modos del relato en el cine de Hollywood. Valladolid, España: Casilla Ediciones. Colección Trama\&Fondo.

González Requena, J. (1997). Emergencia de lo siniestro. Trama\&Fondo, 2, 51-75.

González Requena, J. (1998). Occidente. Lo transparente y lo siniestro. Trama\&Fondo, 4, 7-31. 
MHCJ Vol. 12 (1) | Año 2021 - Prólogo - Páginas 15 a 19 - mhjournal.org

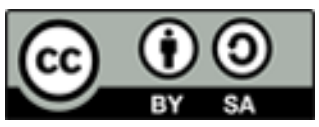

Licencia Creative Commons

Miguel Hernández Communication Journal mhcj.es

\section{Cómo citar este texto:}

José Manuel López-Agulló Pérez-Caballero (2021): "Lo siniestro en el texto audiovisual”, en Miguel Hernández Communication Journal, Vol. 12, páginas 15 a 19 Universidad Miguel Hernández, UMH (Elche-Alicante). DOI: https://doi.org/10.21134/mhcj.v12i.1225 